\title{
Media VS Political Leaders: Contribution in Democratic System
}

\author{
Ghulam Safdar", Ayysha Abbasi, Riaz Ahmad \\ Department of Media Studies, the Islamia University of Bahawalpur, Pakistan
}

Copyright $(\mathrm{O} 2018$ by authors, all rights reserved. Authors agree that this article remains permanently open access under the terms of the Creative Commons Attribution License 4.0 International License

\begin{abstract}
Media and political leaders are two edges of river that work parallel for the promotion of democracy. On one hand, free and fair media is considered as a sign of good democracy, on the other hand, political leaders are considered as flowers of democratic garden. The basic objectives of the research rely to analyze the media's and political leader's contribution to the promotion of democracy. The research concluded that media and political leaders both have major contribution to the promotion of democracy but the majority of people is still impressed by the political leaders rather than media. The popularity of political leaders refers to direct communication, Baradariism and personality impacts. On the other hand less popularity of media causes low literacy rate, lake of readership, less access to media and non-analytical capabilities of media contents.
\end{abstract}

Keywords Media, Political Leaders, Democracy, Political Awareness

\section{Introductions}

The role of media for political communication means that media use to communicate(by political leaders, institutions like parliament, governments, the state, pressure groups, terrorists and others)to inveigle people in the hope of involving them or making them aware of current situations. All these activities are doing for the participation of people in politics Safdar et al., [1]; Shabir et al., [2].

The role of media in politics cannot be deniable. As McQuail [3] said that the organization of democratic politics, nationally and internationally, depends on media and commonly there are no social issues which are addressed without media.

Politics and democracy are inter-linked to each other. Democracy ensures accountable government. Democracy is a system in which people role, selected by people and they serve for people. There is a notion that political leaders often forget their promises. However in third world countries political Governments have really failed to fulfill their promises Shabir \& Safdar, [4]; Safdar et al., [5].

Politics have existed in all over the world. Politics deals with democratic issues, performance, accountability, justice, governance and other matters of people`s daily life. Politics means, power and authority Dahl [6] and the system of power sharing 'shaping and sharing power'. Political process also involves those who did not want to be the part of politics. Participation of a person in politics is called the existing human and societal relationship; it may be intentionally or unintentionally inescapable Shabir et al., [7].

Politics exists in all over the societies. Basic purpose of politics is cooperation, negotiation and struggle in the activities, production and distribution of resources. Politics explain the power and forces which influence and reflect its distribution. Political process is about 'transformative capacity' of social workers and institutions: it is not about governments and governments alone Held, [8]; Safdar et al., [9].

Pakistan is a democratic country, where every citizen has right to elect the government through vote. A vote is reflection of individual's political opinion. An agreed definition of human rights about voting is as 'All the citizens over the age of eighteen have the right of vote Safdar et al., [10].It confirms that rights of the people are preserved." HRCP, [11] "'Voting is a way of expression of opinion for candidate or a party, which have more preference than others Blais, et al., [12]. So it is necessary to know either media play a vital role in increasing turn-out in elections in Pakistan or not.

\section{Politics, Democracy and Participation}

Participation is very necessary in democratic and political process. This is premised that people have 
ultimate authority in any state and their participation is required to complete the political process.

Democracy gives right to public to participate effectively and encourage free debate to set the opinion. Democracy condemns the hoard of power by some elite and supports the distribution of power. Democracy means the authority to rule given by citizens but accountable. But democracy could not be powerful without participation. In short participation is main ingredient of democracy Wikipedia [13].

\section{Objectives}

1. To examine the effects of media and political leaders towards democracy.

2. To evaluate that which factor is more influential (Media or Political Leader).

3. To know about role of media and political leaders in political awareness.

4. To know about the reason of increasing turnout in general elections 2013.

5. To know about the role of media and political parties in nation's unity.

\section{Literature Review}

Muhammad Anwar, Mirza Jan [14] conducts the study on "Role of Media in Political Socialization: The Case of Pakistan. The basic purpose of this study was to explore the new trends of political promotion in media and its special effects in formation of political opinion. To understands political socialization through media. To examines the effects of media on voting behavior. This study develops outline of political socialization in Pakistan. This research explores, explicates and investigates political socialization through media. Media is a helping in socialization. This research explains the political socialization and political communication. The field of political communication interrelates between media and political methods at local, domestic and global level. In democracy person who have not participate in election but he can give his opinion by vote. The study particularly highlights the election campaign, voting attitude and role of media in formation of political awareness.

Held [15] critically analyzes and assesses the various theories of democracy and ways of democracy in all over the world. In the 2006 edition of his book, Models of Democracy, Held include a chapter on 'deliberative democracy', what this means and how public participation forms ingredient of democracy. Held dig-out a serious question as to which the media perform, civil society or the state? He described the nature of relationship between civil society, the media and state.

Hendriks, Vettehen, Hageman \& Snippenburg, [16]
Argue that different researches have explicates the function of mass media in the opinion and behavioral change and others have focused at the role of media as informer only. Some says that it would be changed according the environment of mass media channels, others state that the effects may be various on the basis of dissimilarity in demographic characteristics. A research on the relationship between media usage and political information in the Netherland, that political knowledge comes from reliable and clear media.

Graber [17] says that mass media not only inform us about daily concerns, but also explain clearly and forecast all the incoming possibilities. So media not only inform us but also play an important role I creation of political opinion in democratic system.

Pippa Norris [18] Conduct the study on "The role of the free press in promoting democratization, good governance, and human development" explain that what is the responsibility of the free media in increasing government's performance, democracy and social development? To solve these questions, Part I is about analytical outline, development of proposition and summary of earlier research literature on the topic. Part II is about comparative way of research, confirmation and research plan. This research uses a large- $\mathrm{N}$ cross-sectional assessment to explore the effect of press liberty on various indicators of democracy and good control. Freedom house supplies the standard calculate of press freedom with yearly statistics available from 1992 to 2005.Part III express the division of press freedom and regional movements. Part IV evaluates the effect of these models. The conclusion of study tells that press freedom has increases the chances of good governance and it is very important for democracy.

Mauro Porto [19] tells that in Brazil T.V GLOBO (the biggest television network) is the reason of the go down of authoritarian government in 1985. Superior professionalism and maturity of critical reporting forced the chief executive to take on their communication tactics with the difficult obligations for the superiority of social answerability. He said that reforms at T.V GLOBO contribute to get better the performance of election and accountability system.

Vineet Kaul [20] in his article "Are new media Democracy?" prove that technological advancement in new media has strongly impact on globalization and democratization. Media has the power to make stronger and weaken democracy through their strategies. In some ways globalization itself avoids democracy for own benefits and this is make possible through media technology. Through valuable and responsive programs amend the political and democratic condition in government. Market forces utilize the media only for advertisement of products. If real development is required then political development is necessary than technological. New technological is just a tool of communication, if we want to enjoy democracy then we will have to start with politics not technology. 


\section{Theoretical Framework}

Due to political backgrounds, "Two Step Model" becomes fit in this research. The present research reveal the contribution of media and political leader in the promotion of democracy that described by these theories. Political awareness and bring people close to political process are two main factors. According to the two step model, political leaders have ability to make public opinion. So the researcher has chosen the two step model theoretical support for the present study.

\section{Hypothesis}

H 1: It is more likely that political leaders are best source of political awareness.

H 2: It is more likely that political leaders have more power to convince the people to cast the vote.

H3: It is more likely that political leaders are best representatives of political parties.

H4: It is more likely that media speak more for human rights and power.

H5: It is more likely that political leaders played main role in increasing turnout of general elections 2013.

\section{Research Methodology}

Research methodology is the technique to conduct the research. For the present study, the researcher chooses the survey method to explore the results. For elaborating the results of the study, the researcher used questionnaire as tool for data gathering. The research conducted in the city of Lodhran that is District of Punjab, Pakistan. The sample size of 200 respondents was selected on the basis of available and convenience including males and females aged 18 to 60 years old. In return 183 questionnaires were received. So response was $91.5 \%$.

\section{Variables}

Electronic media and Political Leaders are independent variables of the study and Democracy is dependent variable of the study.

\section{Measurement}

Political leaders who encourage people to caste the vote, intimate public about political party's vision and mission, spread political awareness, represent their political parity, speak for democracy, speak for human rights and power is consider positive role of political leaders.

\section{Data Interpretations}

Table 1. Demographic Characteristics of the Respondents

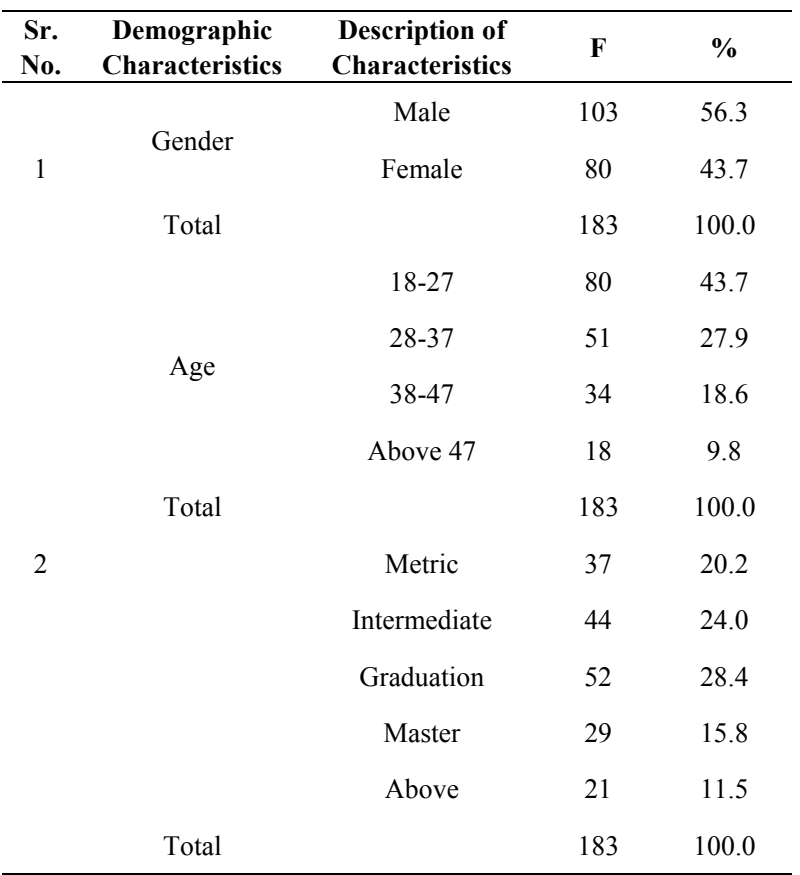

The above table shows the characteristics of respondents. As the table shows that $56.3 \%$ male and $43.7 \%$ female respondents filled the questionnaire which of them $43.7 \%$ were aged between 18 to 27 years old, $27.9 \%$ were between 28 to 37 years, $18.6 \%$ were between 38 to 47 years and $9.8 \%$ respondents were above 47 years old. Furthermore, from selected respondents $20.2 \%$ were matic pass, $24.0 \%$ were intermediate, $28.4 \%$ were graduate $15.8 \%$ were master qualified and $11.5 \%$ respondents were above master qualification.

Table 2. Which is best source of political awareness?

\begin{tabular}{ccccc}
\hline & Frequency & Percent & $\begin{array}{c}\text { Valid } \\
\text { Percent }\end{array}$ & $\begin{array}{c}\text { Cumulative } \\
\text { Percent }\end{array}$ \\
\hline Media & 64 & 35.0 & 35.0 & 35.0 \\
Political Leader & 85 & 46.4 & 46.4 & 81.4 \\
Others & 34 & 18.6 & 18.6 & 100.0 \\
Total & 183 & 100.0 & 100.0 & \\
\hline
\end{tabular}

The above table shows the frequency distribution of source of political awareness. From the collected result, $35.0 \%$ respondents said media is best source for political awareness. $46.4 \%$ respondents said political leaders are best source for political awareness and $18.6 \%$ respondents said other sources are best for political awareness rather than media and political leaders. 
Table 3. Who has main role in making political opinion?

\begin{tabular}{ccccc}
\hline & Frequency & Percent & $\begin{array}{c}\text { Valid } \\
\text { Percent }\end{array}$ & $\begin{array}{c}\text { Cumulative } \\
\text { Percent }\end{array}$ \\
\hline Media & 43 & 23.5 & 23.5 & 23.5 \\
Political Leader & 103 & 56.3 & 56.3 & 79.8 \\
Others & 37 & 20.2 & 20.2 & 100.0 \\
Total & 183 & 100.0 & 100.0 & \\
\hline
\end{tabular}

The above table shows results about making political opinion. According to results, $23.5 \%$ respondents said media has played main role in making political opinion. Whereas $56.3 \%$ respondents said political leaders have played main role in making political opinion. Furthermore, $20.2 \%$ respondents said any others played vital role in making political opinion.

Table 4. Who convinced you to cast the vote?

\begin{tabular}{ccccc}
\hline & Frequency & Percent & $\begin{array}{c}\text { Valid } \\
\text { Percent }\end{array}$ & $\begin{array}{c}\text { Cumulative } \\
\text { Percent }\end{array}$ \\
\hline Media & 52 & 28.4 & 28.4 & 28.4 \\
Political & 78 & 42.6 & 42.6 & 71.0 \\
Leader & 53 & 29.0 & 29.0 & 100.0 \\
Others & 183 & 100.0 & 100.0 & \\
Total & & &
\end{tabular}

The above table shows the result of persuasion towards vote casting. Results showed that $28.4 \%$ respondents due to media they have cast the vote. $42.6 \%$ respondents said political leaders convinced them to cast the vote and $29.0 \%$ respondents said others factors convinced them to cast their vote rather than media and political leaders.

Table 5. Whose role is better for strengthening democracy?

\begin{tabular}{ccccc}
\hline & Frequency & Percent & $\begin{array}{c}\text { Valid } \\
\text { Percent }\end{array}$ & $\begin{array}{c}\text { Cumulative } \\
\text { Percent }\end{array}$ \\
\hline Media & 66 & 36.1 & 36.1 & 36.1 \\
Political Leader & 105 & 57.4 & 57.4 & 93.4 \\
Others & 12 & 6.6 & 6.6 & 100.0 \\
Total & 183 & 100.0 & 100.0 & \\
\hline
\end{tabular}

The above table shows the result about strengthening democracy. Result shows that $36.1 \%$ media playing better role in strengthening democracy. $57.4 \%$ respondents said political leaders playing better role in strengthening democracy, whereas $6.6 \%$ respondents said any other factors are playing better role in strengthening democracy.

Table 6. Who is best representative of political parties?

\begin{tabular}{ccccc}
\hline & Frequency & Percent & $\begin{array}{c}\text { Valid } \\
\text { Percent }\end{array}$ & $\begin{array}{c}\text { Cumulative } \\
\text { Percent }\end{array}$ \\
\hline Media & 45 & 24.6 & 24.6 & 24.6 \\
Political Leader & 138 & 75.4 & 75.4 & 100.0 \\
Total & 183 & 100.0 & 100.0 & \\
\hline
\end{tabular}

The above table shows the result of representation of political parties. Result shows that $24.6 \%$ respondents said media is best representative of political parties. Whereas $75.4 \%$ respondents said political leaders are best representatives of political parties.

Table 7. Who speak more for human power and rights?

\begin{tabular}{ccccc}
\hline & Frequency & Percent & $\begin{array}{c}\text { Valid } \\
\text { Percent }\end{array}$ & $\begin{array}{c}\text { Cumulative } \\
\text { Percent }\end{array}$ \\
\hline Media & 121 & 66.1 & 66.1 & 66.1 \\
Political Leader & 62 & 33.9 & 33.9 & 100.0 \\
Total & 183 & 100.0 & 100.0 & \\
\hline
\end{tabular}

The above table shows the result of human power and rights. Result shows that $66.1 \%$ respondents said media speak more for human power and rights. On the other hand, $33.9 \%$ respondents said political leaders speak more for human power and rights.

Table 8. Who played main role in increasing turnout of General election 2013?

\begin{tabular}{ccccc}
\hline & Frequency & Percent & $\begin{array}{c}\text { Valid } \\
\text { Percent }\end{array}$ & $\begin{array}{c}\text { Cumulative } \\
\text { Percent }\end{array}$ \\
\hline Media & 55 & 30.1 & 30.1 & 30.1 \\
Political Leader & 128 & 69.9 & 69.9 & 100.0 \\
Total & 183 & 100.0 & 100.0 & \\
\hline
\end{tabular}

The above table shows the result of increase of turnout in general elections 2013. Result shows that 30.1\% respondents said media played vital role in increasing turnout of general elections 2013. Whereas, 69.9\% respondents said political leaders played main role in increasing turnout of general elections 2013.

Table 9. Who is good presenter of democracy?

\begin{tabular}{ccccc}
\hline & Frequency & Percent & $\begin{array}{c}\text { Valid } \\
\text { Percent }\end{array}$ & $\begin{array}{c}\text { Cumulative } \\
\text { Percent }\end{array}$ \\
\hline Media & 42 & 23.0 & 23.0 & 23.0 \\
Political Parties & 141 & 77.0 & 77.0 & 100.0 \\
Total & 183 & 100.0 & 100.0 & \\
\hline
\end{tabular}

The above table shows the result of presenter of democracy. Result shows that $23.0 \%$ respondents said media is good presenter of democracy. Whereas $77.0 \%$ respondents said political parties are good presenter of democracy.

Table 10. Who has main role in unity of nation?

\begin{tabular}{ccccc}
\hline & Frequency & Percent & $\begin{array}{c}\text { Valid } \\
\text { Percent }\end{array}$ & $\begin{array}{c}\text { Cumulative } \\
\text { Percent }\end{array}$ \\
\hline Media & 74 & 40.4 & 40.4 & 40.4 \\
Political Leader & 109 & 59.6 & 59.6 & 100.0 \\
Total & 183 & 100.0 & 100.0 & \\
\hline
\end{tabular}

The above table shows the result of nation's unity. $40.4 \%$ respondents said media has played important role in nation unity. Whereas $59.6 \%$ respondents said political leaders have played important role in unity of nation. 


\section{Cross Tabulation and Hypothesis Testing}

For the value of Chi-Square

$$
\chi^{2}=\sum_{i=1}^{n}\left(\frac{\left(O_{i}-e_{i}\right)^{2}}{e_{i}}\right) \text { and under Ho } \chi^{2} \sim \chi_{\alpha,(c-1)(r-1)}^{2}
$$

Hypothesis 1: It is more likely that political leaders are best source of political awareness.

\begin{tabular}{|c|c|c|c|c|c|c|}
\hline & Which & t source of politica & reness? & & Chi Square & P_Yalue \\
\hline & Media & Political Leader & Others & Total & & \\
\hline \multirow{2}{*}{ Male } & 36 & 51 & 16 & 103 & \multirow{6}{*}{$97.221^{\mathrm{a}}$} & \multirow{6}{*}{.000} \\
\hline & $34.9 \%$ & $49.5 \%$ & $15.6 \%$ & $100.0 \%$ & & \\
\hline \multirow{2}{*}{ Female } & 28 & 34 & 18 & 80 & & \\
\hline & $35.0 \%$ & $42.5 \%$ & $22.5 \%$ & $100.0 \%$ & & \\
\hline \multirow{2}{*}{ Total } & 64 & 85 & 34 & 183 & & \\
\hline & $34.9 \%$ & $46.4 \%$ & $18.7 \%$ & $100.0 \%$ & & \\
\hline
\end{tabular}

Hypothesis 2: It is more likely that political leaders have more power to convince people to cast the vote.

\begin{tabular}{|c|c|c|c|c|c|c|c|}
\hline & & \multicolumn{3}{|c|}{ Who convinced you to cast the vote? } & \multirow[b]{2}{*}{ Total } & \multirow{2}{*}{$\begin{array}{l}\text { Chi Square } \\
\text { Value }\end{array}$} & \multirow{2}{*}{ P-Value } \\
\hline & & Media & Political Leader & Others & & & \\
\hline \multirow{4}{*}{ Gender } & \multirow{2}{*}{ Male } & 31 & 43 & 29 & 103 & \multirow{6}{*}{$111.251^{\mathrm{a}}$} & \multirow{6}{*}{.000} \\
\hline & & $30.0 \%$ & $41.7 \%$ & $28.1 \%$ & $100.0 \%$ & & \\
\hline & \multirow{2}{*}{ Female } & 21 & 35 & 24 & 80 & & \\
\hline & & $26.2 \%$ & $43.7 \%$ & $30.1 \%$ & $100.0 \%$ & & \\
\hline \multirow{2}{*}{\multicolumn{2}{|c|}{ Total }} & 52 & 78 & 53 & 183 & & \\
\hline & & $28.4 \%$ & $42.6 \%$ & $29.0 \%$ & $100.0 \%$ & & \\
\hline
\end{tabular}

$\mathrm{N}=183$

$<5 \%$ level of significance

$\mathrm{P}$-value is less than $0.5 \%$. Hypothesis supported.

Hypothesis 3: It is more likely that political leaders are best representatives of political parties.

\begin{tabular}{|c|c|c|c|c|c|c|}
\hline & & \multicolumn{2}{|c|}{ Who is best representative of political parties? } & \multirow{2}{*}{ Total } & \multirow{2}{*}{$\begin{array}{l}\text { Chi Square } \\
\text { Value }\end{array}$} & \multirow{2}{*}{ P-Value } \\
\hline & & Media & Political Leader & & & \\
\hline \multirow{6}{*}{ Gender } & & 26 & 77 & 103 & \multirow{6}{*}{$46.349^{\mathrm{a}}$} & \multirow{6}{*}{.000} \\
\hline & Male & $25.2 \%$ & $74.8 \%$ & $100.0 \%$ & & \\
\hline & \multirow[b]{2}{*}{ Female } & 19 & 61 & 80 & & \\
\hline & & $23.7 \%$ & $76.3 \%$ & $100.0 \%$ & & \\
\hline & \multirow{2}{*}{ Total } & 45 & 138 & 183 & & \\
\hline & & $24.5 \%$ & $75.5 \%$ & $100.0 \%$ & & \\
\hline
\end{tabular}

$\mathrm{N}=183$

$<5 \%$ level of significance

$\mathrm{P}$-value is less than $0.5 \%$. Hypothesis supported. 
Hypothesis4: It is more likely that media speak more for human rights and power.

\begin{tabular}{|c|c|c|c|c|c|c|}
\hline & & \multicolumn{2}{|c|}{ Who speak more for human power and rights? } & \multirow{2}{*}{ Total } & \multirow{2}{*}{$\begin{array}{l}\text { Chi Square } \\
\text { Value }\end{array}$} & \multirow{2}{*}{ P-Value } \\
\hline & & Media & Political Leader & & & \\
\hline \multirow{4}{*}{ Gender } & 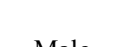 & 75 & 28 & 103 & \multirow{6}{*}{$82.781^{\mathrm{a}}$} & \multirow{6}{*}{.000} \\
\hline & IVIato & $84.4 \%$ & $15.6 \%$ & $100.0 \%$ & & \\
\hline & \multirow[b]{2}{*}{ Female } & 46 & 34 & 80 & & \\
\hline & & $70.0 \%$ & $30.0 \%$ & $100.0 \%$ & & \\
\hline \multirow{2}{*}{\multicolumn{2}{|c|}{ Total }} & 121 & 62 & 183 & & \\
\hline & & $66.1 \%$ & $33.9 \%$ & $100.0 \%$ & & \\
\hline
\end{tabular}

$\mathrm{N}=183$

$<5 \%$ level of significance

P-value is less than $0.5 \%$. Hypothesis supported.

Hypothesis 5: It is more likely that political leaders played main role in increasing turnout of general elections 2013.

\begin{tabular}{|c|c|c|c|c|c|c|}
\hline & & \multicolumn{2}{|c|}{$\begin{array}{l}\text { Who played main role in increasing turnout } \\
\text { of General election 2013? }\end{array}$} & \multirow[b]{2}{*}{ Total } & \multirow{2}{*}{$\begin{array}{l}\text { Chi Square } \\
\text { Value }\end{array}$} & \multirow{2}{*}{ P-Value } \\
\hline & & Media & Political Leader & & & \\
\hline \multirow{4}{*}{ Gender } & Male & 25 & 78 & 103 & \multirow{6}{*}{$61.074^{\mathrm{a}}$} & \multirow{6}{*}{.000} \\
\hline & Male & $24.2 \%$ & $75.8 \%$ & $100.0 \%$ & & \\
\hline & \multirow{2}{*}{ Female } & 30 & 50 & 80 & & \\
\hline & & $37.5 \%$ & $62.5 \%$ & $100.0 \%$ & & \\
\hline \multirow{2}{*}{\multicolumn{2}{|c|}{ Total }} & 55 & 128 & 183 & & \\
\hline & & $30.1 \%$ & $69.9 \%$ & $100.0 \%$ & & \\
\hline
\end{tabular}

$\mathrm{N}=183$

$<5 \%$ level of significance

$\mathrm{P}$-value is less than $0.5 \%$. Hypothesis supported.

\section{Discussion}

Pakistan is democratic country however from the data of birth; Pakistani democracy has not been established in such way that could create better image in the eyes of the world. After a long journey of democracy, $1^{\text {st }}$ political party that complete its tenure of government (5) years is considered PPP elected in 2008. Before that PML (Q) complete its tenure but not considered democratic by the democratic institutions. In the history of Pakistan, $1^{\text {st }}$ time any political party (PPP) handed over the power to another political party (PML-N) which is consider the good sign for the promotion of democracy. For this achievement, main role is not only played by civil societies, political parties, political institutes but also media. To know the answer of the research question, the researcher asked the relevant question to his respondents that and result showed that relationship of media and political leaders are very strong. Both are edges of river that covered and keep control of democratic system.

To explore the relationship of media and political leaders, the researcher asked the relevant questions that "Which is best source of political awareness?" the answers were mixed. $35 \%$ respondents said media is best source of political awareness, whereas $46.4 \%$ respondents argued that political leaders are best source of political awareness. On the other hand, $18.6 \%$ respondents said others sources like peer groups, friends and cast system are better source of political awareness rather than media and political leaders. Hence majority of respondents were in favor of political leaders that they are best source of political awareness.

In second question, researcher asked question about the role of media and political leaders in formation of political opinion. At that point, result were totally in the favor of political leader as only $23.5 \%$ respondents argued in favor of media and said media has played main role in making political opinion. Whereas, more than $1 / 2$ as $56.3 \%$ respondents said political leaders have played main role in making political opinion as political leader attract more their followers towards them. Furthermore, 20.2\% respondents said any others source played vital role in making political opinion like cast system, Brothery and friends etc.

In third question, the researcher asked "Who convinced you to cast the vote?" from the calculated results, the favor was once again towards political leaders but not so much difference in answer as respondents gave mixed answers. 
Results showed that $28.4 \%$ respondents argued that due to media they have cast the vote as they impressed by campaign showed by the media. On the other hand $42.6 \%$ respondents said political leaders convinced them to cast the vote as political leaders have more potential to convince people towards balloting by visiting homes, markets and workplaces and encourage people to cast vote for their development, and $29.0 \%$ respondents said others factors convinced them to cast their vote rather than media and political leaders.

In fourth question, the researcher asked about role of media and political leaders in strengthening democracy. Once again result was in favor of political leaders as $36.1 \%$ respondents said media playing better role in strengthening democracy by auditing political parties and informing public about the political system of the country. Whereas $57.4 \%$ respondents said political leaders playing better role in strengthening democracy as they knows better about political system of the state. Furthermore6.6\% respondents said any other factors are playing better role in strengthening democracy.

In fifth question, the researcher asked "who is better representative of political parties?" Result showed that $24.6 \%$ respondents said media is best representative of political parties and has ability to represent original face of political parties. Whereas $75.4 \%$ respondents said political leaders are best representatives of political parties as they can present and defend their party better as compare to media.

In sixth question, the researcher asked about human power and rights. Now the results were in favor of media as $66.1 \%$ respondents said media speak more for human power and right and act as interface between political parties and public. Mostly respondents said political leaders usually speak for development not human power and rights. On the other hand, 33.9\% respondents said political leaders speak more for human power and rights.

In seventh question, the researcher asked "Who played main role in increasing turnout of general elections 2013?" The results were once again in the favor of political leaders. Result showed that $30.1 \%$ respondents said media played vital role in increasing turnout of general elections 2013. Whereas, $69.9 \%$ respondents gave credit to political leaders and said they played main role in increasing turnout of general elections 2013.

In eighth question, the researcher asked "Who is good presenter of democracy?" Result showed that $23.0 \%$ respondents said media is good presenter of democracy because it looks every angle of event. Whereas $77.0 \%$ respondents said political parties are good presenter of democracy.

In the ninth and last question, the researcher asked "who has main role in nation's unity?" Results showed that $40.4 \%$ respondents said media has played important role in nation unity. Whereas $59.6 \%$ respondents said political leaders have played important role in unity of nation.
To tests the hypothesis, the researcher applied Chi Square test and cross tabulation method was used. According to cross tabulation and chi square test, the chi square value of first hypothesis was 97.221 and P-value was .000 that showed significant association among attributes at $5 \%$ level of significance. So, the hypothesis "It is more likely that political leaders are best source of political awareness" is true.

Chi square value of second hypothesis was 111.251 and P-value was .000 that showed significant association among attributes at 5\% level of significance. So, the hypothesis "It is more likely that political leaders have more power to convince people to cast the vote" is true.

Chi square value of third hypothesis was 46.349 and P-value was .000 that showed significant association among attributes at 5\% level of significance. So, the hypothesis "It is more likely that political leaders are best representatives of political parties" is true.

Chi square value of fourth hypothesis was 82.781 and P-value was .000 that showed significant association among attributes at 5\% level of significance. So, the hypothesis "It is more likely that media speak more for human rights and power" is true.

Chi square value of fifth hypothesis was 61.074 and P-value was .000 that showed significant association among attributes at $5 \%$ level of significance. So, the hypothesis "It is more likely that political leaders played main role in increasing turnout of general elections 2013" is true.

\section{Conclusions}

Media is considered as the fourth pillar of the State. In the last two decade, the media of Pakistan has grown rapidly. This credit goes to Pervez Musharraf. In the present age, media is accessible in all areas of Pakistan. Majority of the people uses TV as a source of information about any political or social issues. In the light of discussions and results, it is concluded that Pakistani media has not satisfactory role for the promotion of democracy in Pakistan. Moreover, majority of the people said that freedom of media is a good sign of democracy and democratic system is not complete without media but media should contribute positively without promoting specific political party.

Literacy rate in Pakistan is not very high so people relay on different source for political awareness and for making political opinion. After the birth of Pakistan, different elections conducted in Pakistan to strengthening democracy but the general elections of 1970 considers more reliable and non-controversial. After a long time, Pakistani politics make big change in its history. After considered atomic power in 1999, Pakistani politics has gained more importance in the world. It is because of $1^{\text {st }}$ Muslim Atomic power in the world but still have different 
question marks on its democratic system and foreign policy.

The research concluded that its reality media plays important role in political awareness but political leaders have more contribution in involving people in political, democratic process rather than media. People more trust on their political leaders and favor their side due to many reason like Baradary, personality likeness. Whereas people think the role of media is controversial regarding democracy and think that face to face communication with leaders is more attracts people rather than on media.

\section{Appendix}

\section{Data Collection Tool}

Personal Information

Education

Age

Gender

Q.1: Which is best source of political awareness?

$$
\text { Media Political leader others }
$$

Q.2: Who has main role in making political opinion

$$
\text { Media Political leader others }
$$

Q.3: Who convinced you to cast the vote?

$$
\text { Media Political Leader Others }
$$

Q.4: Whose role is better for strengthening democracy?

$$
\text { Media political leader Both }
$$

Q.5: Who is best representative of political parties?

$$
\text { Media Political leader }
$$

Q.6: Who speak more for human power and rights?

$$
\text { Media Political leader }
$$

Q.7: Who played main role in increasing turnout of General election 2013?

$$
\text { Media Political leader }
$$

Q.8: Who is good presenter of democracy?

Media Political parties

Q.9: Who has main role in unity of nation?

Media Political leader 


\section{REFERENCES}

[1] Safdar G., Khan A.W., Chaudhry M.U. (2016). Adoption of information technology and its impact on electronic media. Specialty journal of electronic and computer sciences. Vol.2, No.1. Pp.15-21.

[2] Shabir G., Safdar G., Jamil T., Bano S. (2015). Mass Media, communication and globalization with perspective of $21^{\text {st }}$ century. New Media and Mass communication. Vol.34. Pp.11-15

[3] McQuail, D. (2005). “McQuail's Mass Communication Theory". 5th ed. London: Sage.

[4] Shabir G., Safdar G. (2014). Human rights and women's rights in Islam. Ulum-e-Islamia, Vol.19, No.1. Pp.114-126.

[5] Safdar G., Shabir G., Imran M., Seyal A. M., Jamil T.( 2015a). Television is a source of low cost entertainment: A case study of Pakistan. Asian Journal of Social Sciences \& Humanities. Vol. 4, No.1. Pp.24-29

[6] Dahl, R. (1976), Modern Political Analysis. Englewood Cliffs: Prentice-Hall.

[7] Shabir G., Safdar G., Imran M. (2013). Cultural Effects of Urdu drama s of Pakistani TV channels (HUM and GEO Entertainment) on women: A ca se study of Bahawalpur. The Women-Annual Research Journal. Vol.5, Pp.102-120.

[8] Held, D. (2006) Models of Democracy. Stanford: Stanford University Press.

[9] Safdar G., Shabir G., Imran M., Ghaznavi Q.Z. (2015b) "The Role of Media in Increasing Turn-out in Election 2013: A Survey Study of Multan, Punjab, Pakistan" Pakistan Journal of Social Sciences (PJSS), Bahauddin Zakariya University Multan, Vol.35, No.1. Pp. 411-424.

[10] Safdar G., Shabir G., Javed M.N., Imran M. (2015c) “The Role of Media in Promoting Democracy: A Survey Study of
Southern Punjab, Pakistan" Pakistan Journal of Social Sciences (PJSS), Bahauddin Zakariya University Multan, Vol.35, No.2. Pp. 947-968.

[11] HRCP. (2008). "Human right Commission of Pakistan. State of Human rights": An annual report Lahore, Pakistan.

[12] Blais, André, Elisabeth Gidengil, Neil Nevitte, and Richard Nadeau. (2004). "Where Does Turnout Decline Come From?" European Journal of Political Research 43, 2: 221-36.

[13] Wikipedia (e.d) Retrieved on February 10, 2015 from http://en.wikipedia.org/wiki/Democracy

[14] Anwar M., Jan Mirza (2010). "Role of Media in Political Socialization: The Case of Pakistan". Dialogue Vol. 5 No.3.Pp.212-227.

[15] Held, D. (1995) Political Theory and the Modern State: Essay on State, Power and Democracy. Cambridge: Polity Press.

[16] Hendriks, V.P.G., J, Hegemann, C.P.M. \& Snippenburg, L.B.V (2004), "Political knowledge and media use in the Netherlands.". European Sociological Review, 20 (5).Pp-414-424.

[17] Gerbner, G., \& Gross, L. (1976). "Living with television: The violence profile." Journal of communication, 26 (2). Pp.173-199.

[18] Pippa Norris (2006). "The role of free press in promoting democratization, good governance, and human development" World Press Freedom Day. USA. Retrieved from http://www.macrothink.org/journal/index.php/ijhrs/article/ view/2260/1911

[19] Mauro P. (2012), "Media power and Democratization in Brazil: TV Globo and the Dilemmas of Political Accountability" (Routledge).

[20] Vineet K. (2012). “Are new media Democratic?”, Global Media Journal. Vol: 5, No.1. (spring 2012). Retrieved from http://www.aiou.edu.pk/gmj/Archives.asp 